\title{
Independent Virtual English Language Learning: A Case Study In Higher Education
}

\author{
Aprendizaje Virtual Autónomo de la Lengua Inglesa: un Estudio de Caso \\ en Enseñanza Universitaria
}

\author{
Esther Nieto Moreno de Diezmas ${ }^{1}$, María Victoria Guadamillas Gómez², María del Prado \\ García Cano Lizcano ${ }^{3}$ \\ ${ }^{1}$ Departamento de Filología Moderna, Universidad Castilla-La Mancha, España (Esther.Nieto@uclm.es) \\ ${ }^{2}$ Departamento de Filología Inglesa, Universidad Castilla-La Mancha, España (Victoria.Guadamillas@uclm.es) \\ ${ }^{3}$ Departamento de Filología Moderna, Universidad Castilla-La Mancha, España (Prado.GarciaCano@uclm.es)
}

Recibido el 25 de mayo de 2016; revisado el 27 de octubre de 2016; aceptado el 27 de octubre de 2016; publicado el 2 de diciembre de 2016

\begin{abstract}
RESUMEN:
El aprendizaje autónomo y el conocimiento de las herramientas de autoaprendizaje de la lengua extranjera resultan de especial interés en el ámbito de la educación universitaria. Particularmente, se hacen imprescindibles en el área de aprendizaje de lenguas en el que los alumnos necesitan un mayor tiempo de práctica y exposición lingüística para el desarrollo de las destrezas receptivas y productivas. El objetivo de esta contribución es presentar la propuesta de aprendizaje autónomo y aprendizaje virtual llevada a cabo a través de las nuevas tecnologías. Para ello, se diseñaron un grupo de tareas y actividades implementadas a través de Moodle en el marco de un proyecto de innovación docente en el que participan diferentes centros y facultades de Educación de la Universidad de Castilla-La Mancha donde se cursa la materia de Lengua Inglesa I. Se muestran también los resultados iniciales de las percepciones de los alumnos respecto de su aprendizaje autónomo y virtual. Por lo tanto, se trata de un estudio de caso que puede proporcionar conclusiones aplicables a contextos similares donde el aprendizaje de la lengua extranjera a través de contenidos virtuales necesite implementarse. Los resultados iniciales obtenidos indican una respuesta positiva por parte del alumnado en términos tanto de percepción como
\end{abstract}

de participación. Este hecho concede una validez a las tareas y procedimientos aplicados en el desarrollo de la propuesta de aprendizaje autónomo y virtual para el desarrollo de la lengua extranjera.

PALABRAS CLAVE: APRENDIZAJE ACTIVO, APRENDIZAJE DE SEGUNDA LENGUA, EDUCACIÓN SUPERIOR, AULA VIRTUAL.

\begin{abstract}
:
The development of independent and self-learning strategies for Foreign Language Learning is of special interest in Higher Education. In particular, these strategies are essential in the Foreign Language Learning area (EFL), since students need to practise and strengthen their exposure to language so as to develop receptive and productive skills. The goal of this paper is to show how independent and virtual learning are developed by means of ICT. To this end, a group of tasks and activities have been designed, distributed and implemented by means of Moodle in the setting of a teaching innovation project in which different campuses and faculties of Education of the University of Castilla-La Mancha where English $I$ is studied have taken part. Additionally, the initial results in terms of students' perceptions about their independent and virtual learning are shown. Therefore, this paper focuses on a case study at Higher Education in which valid
\end{abstract}


conclusions may be drawn for other similar settings where language learning and virtual learning need to be combined. Initial results suggest the students have responded positively in terms of their perception and participation. This validates the tasks and procedures carried out in the implementation of virtual foreign language learning.

\section{KEYWORDS: ACTIVE LEARNING, SECOND LANGUAGE LEARNING, HIGHER EDUCATION, VIRTUAL CLASSROOM.}

\section{INTRODUCTION}

The development of independent and self-learning strategies at Higher Education Levels is essential in Foreign Language Learning (EFL). It can clearly be seen here that providing students with more opportunities to practise will have a positive influence on their results. Regarding the time and period of exposure to the foreign language, in some studies the benefits of intensive English programs have been observed (Housen, 2012; Serrano, 2012) mainly due to the exposure time. In this regard, Serrano (2012) concludes that "there are certain benefits of concentrating the hours of instruction". The author asserts that "this benefit is clearer when the comparison includes intensive programs that offers more hours of instruction than regular dipfeed programs" (Serrano, 2012: 16). Housen (2012) focuses his attention on the immersion programs in European schools and the advantages of increasing the exposure time to English.

English I is a compulsory course in the degree for Early Childhood Education teacher with a low pass rate. In this setting, a teaching innovation project which encourages students to practice independently via virtual platforms can increase the time of exposure to English and is seen as a possible way of improving students' academic results.

Additionally, self-learning and independent learning techniques are essential in Higher Education, since face-to-face classes have generally been deemed insufficient to address the needs of students. According to Ariza and Viáfara (2009) "being autonomous implies optimizing a viewpoint towards knowledge construction to decide what to learn, when and where learning should be developed, materials to be used and ways to assess one's process" (Ariza and Viáfara, 2009: 89). In the context of this study the issue of giving students the possibility to build their learning and find new opportunities to work on language skills is particularly important.
Furthermore, motivation plays a key role in language learning. Both extrinsic and intrinsic motivation help students improve the way they learn and reach their goals. Boza and Méndez (2013: 333) understand extrinsic motivation to be that which drives one to complete a task in order to reach a goal. In this regard, it is closely related to external rewards which provide recognition in themselves. However, intrinsic motivation bears no relation to any external stimulus, rather it addresses the activities which are generally interesting and motivating for students. Both types of motivation are interrelated and affect academic achievement. Therefore, the design of virtual tasks that students can complete at their own pace could nurture extrinsic and intrinsic motivation, since the activities are presented in an interesting way and students can obtain better marks at the end of the course.

There are numerous studies and research projects which address the use of new technologies in EFL. Some of these studies refer to theoretical issues such as the development of learning to learn competence (Salmerón and Gutiérrez Braojos, 2012). In their study, they consider self-regulating learning to be fundamental to making progress in self-learning and in transforming academic competences into real and useful strategies for university students. Additionally, the authors point out that these learning experiences should be holistic and focus on "competences and strategies development such as self-confidence and self-concept" (Salmerón Pérez and Gutiérrez Braojos, 2012: 7).

Jiménez Raya (2013) focuses on independent language learning at university and its potential; he stresses the importance of nurturing the development of independent students who are able to develop skills, which can be used in different academic fields, effectively. The author points out that creating a friendly environment where learners get used to learning from others and help others is needed. Moreover, Jimenez Raya (2013: 127) thinks that integrating teacher educators in writing and using cases that integrate professional experiences produce "multi-modal texts that help other teachers understand how autonomy can be promoted and supported in the language classroom".

Furthermore, Manzano Vázquez (2015) analyses how the concept of independent learning is developed by means of practical experience in the classroom following the principles of Jiménez Raya et al. (2007). According to the results presented by Manzano Vázquez (2015), independent learning is not a goal in education yet. The author points out that the lack of independence is mainly due to the fact that learners are not held to be responsible for 
their own learning process and syllabus design and assessment processes do not consider self-learning to be a meaningful strategy for learning.

In view of all the considerations above, a group of professors at the University of Castilla-La Mancha decided to design a project which reflects and nurtures self-learning strategies for improving EFL. The teaching innovation project is being implemented in English $I$, at different Faculties of Education of the UCLM. Scaffolding strategies are essential, since students are encouraged to build their own learning according to the level of English they have on starting and their possibilities. A learning plan has been designed to encourage students to participate and develop their learning. This plan includes: the task design, the assessment rubrics and the supporting documents which are conducive to developing metacognitive abilities in order to evaluate and build EFL learning.

The main objectives of the teaching innovation project are:

1. To develop key competences for lifelong learning which allow students to adapt to a changing labour market in which a sense of initiative and learning to learn abilities are required.

2. To foster the use of ICT, particularly, the use of Moodle by professors and students. Sharing documents, creating back-ups or recording and uploading multi-modal texts is encouraged.

3. To introduce innovative and creative practices in a university-level course. In this regard, it is important to stress the use of scaffolding, selfassessment and goal setting.

4. To have more coordination amongst professors who teach the same or similar courses in different faculties and campuses by means of rubrics and common methodologies and evaluation criteria.

5. To support students with different learning abilities by guiding them in their learning process.

6. To support and guide students in their learning of a second language. In this regard, with the project there is an attempt to provide students with tools which can be useful for them in different learning settings.

In order to reach these goals, task design plays an important role. Most of the authors reviewed coincide in the importance of task design in virtual and cooperative projects. A task-based approach in language learning has played a leading role in the last 30 years. One of the main contributors to TBL (Task Based Learning) is Ellis (2003). The author emphasizes the practical utility tasks have and how they act as facilitators in communicative exchanges. From a virtual perspective, tasks can be even more important, since they allow learners to gather together and discuss a particular topic in different environments, involving them in a social exchange which can be shaped differently in future conversations. As Kurek emphasizes: "Apart from simply communicating task content and procedures, task instructions may also compensate for the missing social context and include the discourse for maintaining social affiliation" (Kurek, 2015: 20).

In this article the activities and tasks designed in the project are shown. It also focuses on the perception students have and the initial results obtained by means of implementing the project.

\section{TASK DESIGN: THE LEARNING PLAN}

The importance of task design has been discussed in the introduction, since it plays a significant role in virtual learning environments. The activities that have been put forward to students taking part in the project are related to independent learning and selfevaluation and they guide students towards creating their own learning environment through a guided learning plan. Furthermore, basic dimensions of independent learning and learning to learn competence have been considered such as selfawareness of students' own capacities and selfregulation, or conscious management of their learning process.

In order to develop self-awareness, students have of their capacities and knowledge, two questionnaires have been developed.

The first one was an initial test for students to assess their English level according to the CEFR and so that they can find their starting point in the subject. The test covered grammatical and conversational points and had forty questions on different English levels, so students could answer some questions even if they did not have a good enough level. The results of this test showed that for a considerable number of students, the students' language level was below that required, which justified the implementation of this pedagogical intervention.

The second tool used to foster self-awareness was a questionnaire adapted from the CEVEAPEU instrument for the assessment of learning strategies of university students developed by Gargallo, Suárez-Rodriguez and Pérez-Perez (2009). The main aim of this questionnaire was to promote reflection on the learning processes of students and provide both professors and students with information about the skills and abilities which need to be improved. 
Moreover, to encourage self-regulation and conscious management of the learning processes of students, professors created four different types of documents:

1. Repository of online resources which enable students to develop independent and virtual learning (videos, activities, online exercises, etc.). These resources are available for different levels (basic, intermediate, advanced) and classified by skills (reading, writing, speaking and listening). There are also resources for general English practice and online dictionaries. The resources selected by professors are varied and provide an extensive setting for the development of the different language skills (for example, they include more than 200 listening activities of intermediate level). Table 1 shows the links to the activities classified by skills:

Table 1. Repository of online resources.

\begin{tabular}{|c|c|}
\hline Skill & Link \\
\hline $\begin{array}{l}\text { Reading } \\
\text { practice }\end{array}$ & $\begin{array}{c}\text { http://www.livebinders.com/play/play?id } \\
=910606\end{array}$ \\
\hline $\begin{array}{l}\text { Writing } \\
\text { practice }\end{array}$ & $\begin{array}{c}\text { http://www.livebinders.com/play/play?id } \\
=910603\end{array}$ \\
\hline $\begin{array}{l}\text { Listening } \\
\text { practice }\end{array}$ & $\begin{array}{c}\text { http://www.livebinders.com/play/play?id } \\
=910605\end{array}$ \\
\hline $\begin{array}{c}\text { Speaking and } \\
\text { Conversation } \\
\text { practice }\end{array}$ & $\begin{array}{l}\text { http://www.livebinders.com/play/play?id } \\
=910602\end{array}$ \\
\hline $\begin{array}{c}\text { Exam skills } \\
\text { practice: Use } \\
\text { of English }\end{array}$ & $\begin{array}{c}\text { http://www.livebinders.com/play/play?id } \\
=910608\end{array}$ \\
\hline Dictionaries & $\begin{array}{c}\text { http://www.livebinders.com/play/play?id } \\
=910609\end{array}$ \\
\hline $\begin{array}{l}\text { Main link to } \\
\text { activities }\end{array}$ & $\begin{array}{c}\text { http://www.livebinders.com/shelf/view/7 } \\
3568\end{array}$ \\
\hline
\end{tabular}

2. An inventory of tasks related to every didactic unit of the textbook was also created by professors aimed to particularly reinforce productive skills (speaking and writing). Students must upload to Moodle their recording, reading aloud and writing tasks. Table 2 shows some of the tasks designed for unit 1.

Table 2. Example of tasks

\begin{tabular}{|c|c|c|}
\hline $\begin{array}{l}\text { Recording tasks } \\
\left(2^{\prime}-3 \text { ' minutes }\right)\end{array}$ & $\begin{array}{c}\text { Writing tasks } \\
(100-120 \\
\text { words })\end{array}$ & $\begin{array}{c}\text { Reading } \\
\text { tasks }\end{array}$ \\
\hline $\begin{array}{c}\text { Talk about your } \\
\text { family, } \\
\text { studies/job, home, } \\
\text { likes/dislikes }\end{array}$ & $\begin{array}{l}\text { Write a report } \\
\text { with this } \\
\text { headline: } \\
\text { "woman finds a } \\
\text { suitcase full of } \\
\text { money on train" }\end{array}$ & $\begin{array}{l}\text { Read the text } \\
\text { "Child of our } \\
\text { time" (page } \\
\text { 12) }\end{array}$ \\
\hline
\end{tabular}

\begin{tabular}{ccc}
\hline $\begin{array}{c}\text { Speak about two } \\
\text { important dates } \\
\text { connected with } \\
\text { your family. }\end{array}$ & $\begin{array}{c}\text { Write an email } \\
\text { about "situation } \\
1 " \text { (page 10). }\end{array}$ & $\begin{array}{l}\text { Read the text } \\
\text { "The money } \\
\text { programme: } \\
\text { Second Life" } \\
\text { (page 16). }\end{array}$ \\
\hline $\begin{array}{ccc}\text { Talk about your } \\
\text { achievements } \\
\text { things you have } \\
\text { done or you have } \\
\text { not done). }\end{array}$ & $\begin{array}{c}\text { Write an email } \\
\text { about "situation }\end{array}$ & $\begin{array}{c}\text { Read the text } \\
\text { BBC Hustle } \\
\text { (page 28). }\end{array}$ \\
\hline $\begin{array}{c}\text { What are the } \\
\text { stereotypes of men } \\
\text { and women in }\end{array}$ & $\begin{array}{c}\text { Write a story } \\
\text { using as many } \\
\text { expressions on } \\
\text { page 22 as you }\end{array}$ & $\begin{array}{c}\text { Read the text } \\
\text { "How do you } \\
\text { know if }\end{array}$ \\
& can. & $\begin{array}{c}\text { someone is } \\
\text { lying?" (page } \\
26) .\end{array}$ \\
\hline
\end{tabular}

Apart from recordings, writing and reading tasks, there are other suggested activities which focus on pronunciation, speaking and listening, vocabulary lists and online grammar exercises.

3. Two different tools were created to encourage self-assessment strategies: self-assessment questionnaires and rubrics of evaluation for both speaking and writing. After every writing or speaking task, students have to evaluate their work, first by online completion of the corresponding selfassessment questionnaire, and then by self-assigning a score using the rubrics. The self-assessment questionnaires have a check list structure and focus on text organization, grammar and vocabulary and their main objective is for to students to learn to avoid common mistakes. The rubrics of evaluation are the ones that professors use to evaluate productive skills in the final test.

4. The forth tool of the learning plan is the discussion paper on the learning process, designed to support self-learning regulation. Students have to reflect in this document on what they have learnt in every lesson, how they learn better, what their achievements are and in what areas they have improved. They also have to make decisions about their learning process and to work on their weaknesses, using activities from the repository of online resources. In this way, students learn to selfregulate their learning and learn according to their needs and at their own pace.

\section{RESEARCH QUESTIONS AND METHOD}

The main research question guiding this study stems from the inquiry into the opinion students have regarding the effectiveness and usefulness of the teaching innovation project, and particularly about 
their impressions on the learning plan and on each element it is made up of.

To answer the research question a combination of quantitative and qualitative methodology was used, since each provides valuable information for understanding the other. First, a Likert type scale was applied, since it is the most commonly used one to measure attitudes and opinions (Cohen, Manion and Morrison, 2000). The format of a typical fivelevel Likert item was used: 1 = Strongly disagree, 2 $=$ Disagree, $3=$ Neither agree nor disagree, $4=$ Agree and $5=$ Strongly agree .

The questionnaire consisted of 18 questions designed to sound out the attitudes and opinions of students regarding the basic instruments of the educational intervention: repository of online resources, the inventory of tasks, the self-assessment questionnaires, the rubrics of evaluation, and the discussion paper on the learning process. The questionnaire was developed using google forms and filled out by students from Moodle and it was intended to obtain data about the opinions and attitudes students had in the first phase of the project implementation, hence enabling appropriate decisions to be taken for the second phase of its implementation.

As for the participants, the questionnaire was answered by 93 students divided into different classes. Regarding the interpretation of the questionnaire results, since the intervals between values could not be considered to be equal (Blaikie, 2003), ordinal data is described in this paper using response percentages.

In addition, a focus group interview was carried out in order to obtain a more in-depth understanding of the meaning of the answers the students gave on the Likert questionnaire. Although group interviews and focus groups usually have an exploratory purpose (Fontana and Frey, 2005), this time we found it very interesting to observe the students themselves collaborating in making sense of what their peers said, so they took on an active role in the analysis and explanation of the data. This strategy enabled us to construct meaning and obtain an indepth interpretation of the quantitative data.

The interview was conducted with a group of 12 students for 60 minutes. A confident and safe atmosphere was created, without judging or rebutting any of the answers, and interviewees were made aware of how important their contribution was to the study, as recommended by Gurdián (2010) and Vargas (2012) among others. During the interview, students were shown graphs derived from the analysis of the Likert questionnaire, for them to offer an interpretation or explanation of the results.

\section{RESULTS AND DISCUSSION}

The opinions and perceptions collected through the Likert questionnaire and the focus group interview on the key instruments of the pedagogical intervention of the learning plan included in the teaching innovation project are explained below.

\subsection{The learning plan and independent learning}

The Bologna process and the establishment of ECTS entails a change of perspective to focusing not just on what work students do inside the classroom, but also what they do outside it. What university students do and how they organize their time devoted to independent learning has become an issue in research in recent years (Ruiz-Gallardo, Geraldo Gonzalez and Castaño, 2016).

In this regard, in this study participants have been shown to be sensitive to the actual meaning of ECTS, as none of the respondents believed they could make progress in the subject without independent work outside class time, and $94.6 \%$ agreed or strongly agreed that independent learning was essential to complete their learning process.

In this sense, most students thought the tasks in the learning plan made them spend more time learning English (68.9\% agreed or strongly agreed with this statement). Most students agreed or strongly agreed $(51.1 \%)$ with the statement that the learning plan helps them organize their independent work, although a high percentage of students, $31 \%$, chose the option "neither agreeing nor disagreeing".

In the group interview students were asked about this issue and several explanations for the high percentage of neutral opinions were given. Many students stated that they had started the course with a very low level of English and they had to receive private classes, so much of the time that ought to have been devoted to independent work was taken up by attendance of these individual classes instead of fulfilling the learning plan. They also argued that not all classmates were carrying out the learning plan with the same intensity and involvement, and suggested that those students who did not complete the tasks set on time were not developing their strategies in the same say as those students who did. 


\subsection{Self-assessment questionnaires}

The students showed a positive view of selfassessment questionnaires. Only a small percentage (6.9\%) of participants evaluated these selfassessment questionnaires negatively. Conversely, $49.4 \%$ of students agreed or strongly agreed that self-assessment questionnaires helped them be aware of their own mistakes and review what they had produced. The percentage of students who neither agreed or disagreed with this statement was more than a quarter $(27 \%)$. On the other hand, students considered the self-assessment questionnaires to be more useful for written production than those referring to oral production. 51.1\% agreed or strongly agreed that self-assessment questionnaires for written production helped them improve planning, structuring and reviewing grammatical and lexical aspects of written texts. However, the above percentage dropped slightly to $47.8 \%$ when it came to assessing how far the self-assessment questionnaire contributed and helped oral production.

Similar results were yielded in the group interview. Most students considered the selfassessment questionnaires for written productions to be far more useful than those used for oral productions. They argued that it was easier to acquire the models for structuring and revision put forward in the tasks during and after producing a piece of writing since it is possible to correct, go back, rephrase, etc., while in oral production it is more complicated to apply their knowledge and make it their own. "We know that / v / and / b / are pronounced differently, but as you speak you don't realize the way you do it" (Participant 5). Another participant says "Maybe at first you think what you are going to say, but then you say what comes into your head at that moment and you do not think about the self-assessment questionnaire" (Participant 2). As for the percentage of indecisive students (around a quarter), the explanation is similar to that given above: students who did not have a set routine for working on their learning plan did not have a clear idea about the usefulness and meaning of the selfassessment questionnaires.

Finally, we believe the fact that the selfassessment questionnaires have also been criticized is of great significance. Students stressed there was a need to develop different questionnaires for every written and oral task, as at present there is only one model that is applied to all compositions and monologues. They believed that responding to the same questions was tedious. Moreover, they thought that this repetition, rather than helping them to memorize the model, made them fill in their answers automatically, without thinking, as it became a mere routine.

\subsection{Rubrics of evaluation}

The rubrics of evaluation obtained a more favourable opinion than the self-assessment questionnaires did regarding their usefulness for modelling and reviewing oral and written productions as well as reflecting on learning. $74.2 \%$ of students agreed or strongly agreed with the fact that the rubrics of evaluation are important for understanding what items the teacher will assess in written and oral productions.

Additionally, it must be stressed that no student disagreed with its usefulness in this regard. However, $21.3 \%$ of students neither agreed nor disagreed in this sense. This is one of the issues that was brought out in the group interview. Students expressed their fears about not being able to interpret the rubrics in the same way as teachers did and that it was not so easy to obtain the minimum level required for each section of the rubrics.

Nevertheless, students agreed or totally agreed $(66.6 \%)$ with the necessity of knowing rubrics of evaluation for written and oral production in order to get good results in the tests, and to a lesser extent, $63.3 \%$ recognized the usefulness of the rubrics to reflect on the progress of their own learning. In conclusion, the instrument the students more positively valued was the rubrics of evaluation.

\subsection{Discussion paper on the learning process}

$63.3 \%$ of students agreed or strongly agreed that the discussion paper they had to write at the end of each unit helped them reflect on the content they needed to acquire in each unit (grammar, vocabulary, etc.), while the percentage of students who neither agreed nor disagreed was $26.7 \%$. The perception of the usefulness of this discussion paper to detect the strengths and the areas for improvement was similar to that in the previous question, since $64.3 \%$ of students agreed or strongly agreed in this respect, while the percentage of undecided students was $26.4 \% .31 .4 \%$ of students agreed or strongly agreed that it was difficult to draft the discussion paper, while $24.8 \%$ disagreed or strongly disagreed with this statement. The percentage of students who neither agreed nor disagreed rose to $43.8 \%$.

In the group interview, students explained that they had never written a similar discussion paper, so they did not know if they were doing it well. As an 
area of improvement for the second phase of the project we plan to give more guidelines in order to help the students in their writing as well as try to make drafts in class. Within the self-regulation process, the discussion paper was intended to be a starting point for providing information for the students about the areas where they need more practice and therefore it would help them in decision-taking about the organization of their own independent learning, including the use of the repository of online resources. However, only $27 \%$ of students reveal that they carried out additional activities from the repository of online resources; $22.4 \%$ admit that they did not usually do them, and the percentage of students who neither agreed nor disagreed rose dramatically to $50.6 \%$. Being the students asked on this issue in the group interview, several opinions have been set out. As positive aspects the students emphasized that "different kinds of activities could be found in the repository and they could choose the skills they need to strengthen" (Participant 5), "it's good that the material is organized by difficulty so you can start with activities according to your level and then go increasing" (Participant 4) "it is much better to use the repository of online resources than having to find activities on you own, as you can waste time and not be able to find such good resources as the ones given by the teacher" (Participant 3). Perceptions of other students are not so positive: "there are many activities, too many activities..." (Participant 1), "You go there and you get lost ..." "I do not know exactly what to do ..." (Participant 7). These statements seem to confirm the difficulty students have in managing and filtering digital information, even if it has already been prepared and organized by the teacher and classified by skills and levels. Some students stated: "But...will it be asked in the exam?" (Participant 6), "Sometimes in the reading tasks we can find different vocabulary or topics from the ones worked in class and maybe there will not be similar topics in the test, so it is much better to revise what has been studied in class" (Participant 7). Other student explains: "I am very bad at listening, therefore I try to practise this skill with the online material, but telling the truth, I do not see my improvement" (Participant 2). From the above, it may be inferred that the main objective the students had was to pass the subject rather than actually learn. They felt pressured by the time they had available for studying, so they wanted to optimize it by focusing only on the tasks and topics they will be asked about in the final exam. Students are not aware that learning a foreign language is a slow and long process, they want to reach their goals in little time. Another important concept brought out from the interviews is that autonomous learning or independent digital learning is considered hard work by students, who prefer to learn in a more limited and organized way.

\subsection{Relation between the learning plan and the improvement in learning}

Students believed that the greatest benefit of the learning plan was its focus on improving vocabulary acquisition, according to $61.8 \%$ of participants. The following areas most benefited were written production $(51.1 \%$ of students agreed or strongly agreed with this statement) and grammar (48.3\%), while $42.1 \%$ of students agreed and totally agreed that the learning plan enabled them to improve their oral production.

When students were asked in the questionnaire about the general contribution the learning plan made to their improvement in the subject, $39.4 \%$ agreed and strongly agreed with the statement that the learning plan had helped them to improve their English language skills, while $40.4 \%$ neither agreed nor disagreed. In the group interview students displayed a positive view about the learning plan, but they explained that it was difficult for them to assess the way they were getting better. They also explained that the learning plan provided guidelines for further practice whose results were not often seen immediately. They considered that learning a foreign language bore little relation to learning another subject. They could study vocabulary and understand grammatical rules, but were, perhaps, unable to use them in their written and oral productions with fluency and accuracy.

Two main conclusions may be inferred from the arguments discussed previously. On the one hand, students found it very difficult to internalize their progress and evaluate themselves, which is one of the basic dimensions of the competence of learning to learn and independent learning. On the other hand, the fact was dawning on the students that language learning, unlike other subjects, is a process which develops over a long time and needs very intensive exposure to input. Therefore, they do not achieve success as soon as they do in other subjects.

\section{CONCLUSIONS}

In this paper we analyse the views and perceptions of a group of university students regarding the implementation of a teaching innovation project, 
whose main objective was to improve independent learning of the English language by means of online learning and using Moodle (Campus Virtual). The teaching innovation project consisted in the design of a learning plan including an inventory of tasks, a selection of online resources for the autonomous learning and several self-assessment tools as questionnaires and rubrics. At the end of the every unit, students had to reflect on their learning process, make decisions about how to improve their level of English and organize their own learning plan.

In order to gather the opinions the students had on the innovation project and the learning plan, quantitative and qualitative methodological techniques were used, by means of a Likert type questionnaire and a focus group interview, which enabled to make sense of the questionnaire responses.

The view of students had about the learning plan designed was quite positive. The most benefited areas, according to students' perceptions were, in this order: vocabulary acquisition, development of written skills, grammar and improvement of in oral production. They also considered the rubrics of evaluation to be more useful than the selfassessment questionnaire to model, revise and assess their productions. Over 25\% of students were undecided (neither agreeing nor disagreeing) on some issues. According to the results in the group interview, the reasons for this high percentage may have been due to the different level of student involvement in carrying out the activities of the learning plan and therefore the different handling of the tools included therein.

From the responses of the focus group interview, it could also be inferred that students struggled with their self-assessment as well as in trying to understand and apply the various instruments of selfevaluation.

Moreover, it was found that students encountered problems when they tried to self-regulate their learning and organize it independently. This was seen in the limited use the students did of the repository of online resources.

In this sense, the group interview revealed that the main goal of the students was to achieve successful marks on the subject, instead of learning and reflecting on their own learning processes. Therefore, it was more important for them for the teacher to explain clearly "which issues will be asked in the exam and which ones will not" (Participant 7) rather than improve their independent learning techniques, self-assessment and selfregulation.
In this setting, it is even more valuable to enhance independent and digital learning in university students, since it will become a key tool for improving their lifelong learning and for their personal, social and professional development.

\section{RESEARCH LIMITATIONS AND FUTURE RESEACH}

In this study the views and perceptions of students regarding the learning plan, which was the main action of the teaching innovation project described in this paper, were analysed. The study was conducted before the end of the course, so, lacking academic results of the final evaluation, we only could research the opinion of students about the impact of the various instruments designed on their learning process. However, it would be interesting to determine the impact of the teaching innovation project in improving students' grades by comparing them with the results of previous academic years. It would also be of great interest to see whether there is any relation between the academic performance of students and the degree and intensity of their participation in the teaching innovation project by means of their uploading to Moodle, the tasks, the self-assessments and the discussion paper on their learning process.

On the other hand, the results of this study provide valuable information to improve the design of some of the instruments and its implementation. Such is the case of the self-assessment questionnaires and the discussion paper on the learning process. In the first case, it will be necessary to develop an evaluation questionnaire tailored to each of the tasks. As for the discussion paper, it would be useful to provide guidance to students for structuring it and also to help them effectively use it to organize, plan and carry out their learning process.

In short, this study provided us with a starting point for further work that is twofold: from a pedagogical point of view, it has made us realize the actual needs of improving some of the instruments of the learning plan. On the other hand, it is important to go further in proving its effectiveness through future research aimed at determining the impact of the learning plan on academic performance of students. 


\section{Acknowledgments}

The teaching innovation project described in this paper was granted by the Vice-rectorate for teaching of the University of Castilla-La Mancha in the IX call for teaching innovation projects. We would also like to thank the students for their collaboration.

\section{REFERENCES}

Ariza, A. and Viáfara, J. (2009). Interweaving autonomous learning and peer-tutoring in coaching EFL studentteachers. PROFILE Issues in Teachers' Professional Development, 11(2), 85-104.

Blaikie, N. (2003). Analyzing Quantitive Data from Description to Explanation. London, UK: SAGE.

Boza Carreño, A. and Méndez Garrido, J. M. (2013). Aprendizaje motivado en alumnos universitarios: validación y resultados generales de una escala. Revista de Investigación Educativa, 31(2), 331-347.

Cohen, L., Manion, L. and Morrison, K. (2000). Research Methods in Education. London, UK: Routledge.

Ellis, R. (2003). Task-Based Language Learning and Teaching. Oxford: Oxford University Press.

Fontana, A. and Frey, J. (2005). The Interview, from neutral stance to political involvement. In N. K. Denzin and S. Lincoln (Comp.), The Sage Handbook of Qualitative Research (pp. 695-727). London, UK: Sage.

Gargallo, B., Suárez-Rodriguez, J. M. and Pérez-Perez, C. (2009). El cuestionario CEVEAPEU. Un instrumento para la evaluación de las estrategias de aprendizaje de los estudiantes universitarios. RELIEVE, 15 (2), 1-31.

Gurdián, A. (2010). El paradigma cualitativo en la investigación socio-educativa. San José, Costa Rica: Editorial Universidad de Costa Rica.

Housen, A. (2012). Time and amount of L2 Contact Inside and Outside the School: Insights from the European School. In C. Muñoz (ed.), Intensive Exposure Experiences in Second Language Acquisition (pp. 111-141). Bristol: Multilingual Matters.

Jiménez Raya, M., Lamb, T. and Vieira, F. (2007). Pedagogy for Autonomy in Language Education in Europe Towards a Framework for Learner and Teacher Development. Dublin: Authentik.

Jiménez Raya, M. (2013). Exploring Pedagogy for Autonomy in Language Education at University: Possibilities and Impossibilities. In M. Pérez Cañado (ed.), CompetencyBased Language Teaching in the European Higher Education Area. New York: Springer.

Kurek, M. (2015). Designing Tasks for Complex Virtual Learning Environments. Bellaterra Journal of Teaching and Learning Language and Literature, 8(2), 13-32.

Manzano Vázquez, B. (2015). Pedagogy for autonomy in FLT: An exploratory analysis on its implementation through case studies. Porta Linguarum, 23, 59-74.

Ruiz-Gallardo, J. E., Geraldo González, J. L. and Castaño, S. (2016). What are our students doing? Workload, time allocation and time management in PBL instruction. A case study in Science Education. Teaching and Teacher Education, 53, 51-62.

Salmerón Pérez, H. and Gutiérrez Braojos, C. (2012). La competencia de aprender a aprender y el aprendizaje autorregulado. Profesorado Revista de Curriculum y Formación de Profesorado, 16 (1): 5-13.
Serrano, R. (2012). Is Intensive Learning Effective? Reflecting on the Results from Cognitive Psychology and the Second Language Acquisition Literature. In C. Muñoz (ed.), Intensive Exposure Experiences in Second Language Acquisition (pp. 3-22). Bristol: Multilingual Matters.

Vargas Jiménez, I. (2012). La entrevista en la investigación cualitativa: nuevas tendencias y retos. Revista CAES, 31 (1), 119-139. 